Artillery School in 1892. He had developed an interest in chemistry several years before this and established a private laboratory from his small earnings; because of the nature of the curriculum and the instruction, most of his chemistry was selftaught. He remained at the Michaelovsky Artillery School as an instructor in chemistry and later became its first professor of chemistry. During 1896-97 he was sent to Western Europe, where he studied with von Baeyer in Munich and with Vielle and Sarraut in Paris, and in 1907 the chair of chemistry in the University of St. Petersburg was added to his duties.

During the First World War, Ipatieff was a lieutenant-general in charge of the Russian chemical industry, and because of his distinction he continued to hold high office during the Soviet regime. From 1921 until 1926 he was a member of the Supreme Economic Council of the Soviet Union, and in 1927 an institute for the study of high-pressure reactions was established for him. However, the scientific climate was increasingly distasteful to him and, in the company of his wife, he managed to leave Russia. After a short stay in Germany, he went to the United States in 1931 to become a lecturer in chemistry at the Northwestern University, Evanston, Ill., and director of research at the Universal Oil Products Co. In 1938 , in order more easily to pursue purely academic research and to be able to teach his techniques to students, he established the Ipatieff High-Pressure Laboratory at the Northwestern University with the support of the Universal Oil Products Co., and he was actively engaged in his positions at the University and with the Company until two weeks before his death.

Commencing his career in the United States at an age when most men retire, Ipatieff published thereafter about a hundred and fifty scientific papers and obtained more than two hundred patents. He had already published some two hundred papers before he left Russia, starting with one in 1892, "Chemical Investigation of the Structure of Steel". The many honours that he received are too numerous to enumerate here, but mention should be made of the fact that he was the only man to have held regular membership in the national academies of science of both the U.S.S.R. and the United States (though his membership in the former, along with all other Russian honours, was cancelled by the Soviet Government in 1936 following his repeated refusal to return to the U.S.S.R. His wife, Barbara Demitrievna, with whom he had celebrated in 1952 their sixtieth wedding anniversary, survived him but a few days and died on December 9. Of their children, a son and a daughter still live in the U.S.S.R., one son was killed in the First World War and another lost his life while fighting tropical fevers in the Belgian Congo.

Ipatieff was a man of charm and kindness who enjoyed social contacts. He was always ready with encouragement and assistance to anyone interested in advancing science. He was an indefatigable worker who set himself a hard schedule, any disturbance to which upset him, and in particular his rare illnesses especially outraged his sense of order. While his life was primarily devoted to science, he had a number of other interests. He was a devout member of the Russian Orthodox Church, though no narrow sectarian, and he read widely in literature. In his earlier days he was an expert rider ; fishing and swimming mainly occupied his vacations until a fow years ago, and he was a great walker.
After some work of interest in ordnance and some in classical organic chemistry, of which that on the structure and synthesis of isoprene was particularly notable, Ipatieff became interested in heterogeneous catalysis, for he thought that high pressures of hydrogen would facilitate the hydrogenation of organic compounds. In testing this hypothesis he had to develop equipment for working at high pressures, in which task he was helped by his training as an artilleryman, and in 1903 he developed the first practical experimental autoclave for working at high pressures. $\mathrm{He}$ devoted much of his life to the exploitation of this discovery in a wide field of catalytic reactions, particularly hydrogenation. His pioneer work in high-pressure hydrogenation had revolutionary effects upon laboratory and technical procedures in many fields of chemistry. He was the first to recognize the use of promoters in heterogeneous catalysis. His work in the United States is notable for the discovery of the 'solid phosphoric acid' catalysis for the polymerization of olefines, for the discovery of the alkylation of olefines by isoparaffins and for work in the isomerization of alkanes. His research was one of the main sources of the revival of interest in hydrocarbon chemistry and of aliphatic chemistry in general and may be considered as the origin of much of modern petroleum technology.

Several months ago the Universal Oil Products Co. entered into negotiations with Northwestern University to establish the Vladimir Ipatieff research professorship, by which the Company will grant the University 25,000 dollars annually for the salaries of the professor and an assistant and for other expenses. It is a source of much gratification that Ipatieff had been informed of the final details of this professorship a fow days before his death.

ROBERT L. BURWELI, JUN.

\section{Dr. K. G. Blair}

Kenneth Groyne Blarr, who at the time of his retirement was a deputy keeper of the Department of Entomology of the British Museum (Natural History), died at Freshwater, Isle of Wight, on December 11. Born at Nottingham on December 22, 1882, he was educated at Highgate School and Birkbeck College, London. After a brief period spent in other government offices, he transferred in 1910 to the Natural History Museum, being appointed assistant in the Department of Zoology, which then included entomology.

Under Dr. C. J. Gahan, Blair was put in charge of a large section of the Coleoptera comprising principally the Heteromera, which had perforce been largely neglected for many years. His systematic overhaul of these collections resulted in the publication of numerous papers concerned with the critical revision of genera and species, the description of new ones, the elucidation of the work of the early authors, a catalogue of the Pythidæ and Pyrochroidæ, and so on. Concurrently he published many papers of faunistic interest, based largely on collections made by various expeditions. These ranged from Mt. Everest, Krakatau, Samoa, Fiji, the Mentawi Islands, Christmas Island and the Marquesas in the East, through southern Arabia and South Africa to the Galapagos Islands.

But it would be wrong to base any estimation of Blair's contributions to entomology solely on the 
evidence of these works. He was at his best in the field among living insects, where he had a quite amazing flair for the 'good thing' and in consequence added considerably to our knowledge of the British fauna in nearly all orders of insects. Insect luminosity, and the complex inter-relationships of the inhabitants of plant galls, fascinated him and were the subject of several papers; fossil insects, myrmecophiles, insect stridulation and the morphology of beetle larvæ also attracted his attention. Up to the time of his retirement, due to ill health attributable to service with the Seaforth Highlanders during the First World War, he took a most active part in the proceedings of the societies to which he belonged. He was president of the South London Natural History Society in 1920, 1921 and 1931 and of the Royal Entomological Society during 1940-41. He is mourned by a very wide circle of friends, who will always remember gratefully the help he gave so freely and modestly to all who sought it, from his unusually wide store of knowledge and experience.

N. D. RILEY

\section{Mr. E. G. Dymond}

EDmund GrLbert Dymond died suddenly in Edinburgh on October 26. He was born at Hairwain, South Wales, in which town his father was engaged in business as a civil engineer. Between the ages of twelve and eighteen persistent ill-health made regular schooling impossible, but at the latter age he entered St. John's College, Cambridge, and thereafter lived an active and productive life. Only his early death reminded his friends that his energy and enthusiasm must often have outmatched his strength.

Dymond obtained first-class honours in physics in Part 2 of the Natural Sciences Tripos in 1922, and was awarded a Hutchinson research studentship by St. John's. In 1925 his College elected him to a fellowship. He had spent two of the intervening years in research at the Cavendish Laboratory, and the third as International Education Board Fellow at Göttingen. The following year he spent in Princeton. During the whole of this time, and throughout the next five years, when he was back in Cambridge, Dymond investigated various problems of electron collisions in gases.

In 1932 Dymond moved to Edinburgh, first as Carnegie Teaching Fellow, then as lecturer, and after 1948 as reader in natural philosophy. Soon afterwards his main research interest changed, and as a member of the Wordie expedition to North-West Greenland in 1937 he obtained records of cosmic ray intensity, using balloon-borne apparatus up to a height of about twelve miles. About the same time he released his first balloons from the Edinburgh district in similar investigations. This work remained interrupted throughout the Second World War, but Dymond continued his contribution to upper-atmosphere physics at Kew Observatory, where he developed and perfected the British radio-sonde. $\mathrm{He}$ returned to Edinburgh in 1946.

Building up equipment again after the War, and gathering a small research team around him, he was favourably placed to add considerably to our knowledge not only of cosmic radiation at great heights, but also of ozone distribution. However, only one major investigation was complete at the time of his death. The progress of the others will be slower for lack of his direction.

N. FeATHER

\section{Prof. L. Lapicque}

Colleagues and friends in every country will regret the death, at the age of eighty-six, of Louis Lapicque, professor at the Sorbonne during 1919-36 and the leading figure in French physiology. His early researches were biochemical and they were followed by an expedition to the Andaman Islands to collect anthropological data; but in 1902, after his return to France, he took up the studies of excitability in nerve and muscle for which he became famous.

Lapicque used new methods to explore the relation between the duration and the strength of an effective electric stimulus : his curves showed the inadequacy of Nernst's treatment and led to new ideas based on the measurement of the 'chronaxie', a quantity giving the time factor of the excitation process. In collaboration with Mme. Lapicque he studied the chronaxie relations of a wide variety of tissues and demonstrated their essential similarity. The theory of isochronism which he afterwards developed may not have had all the far-reaching implications suggested by it, but his ingenious experiments and trenchant exposition have a classical quality which will be long remembered.

Between the two World Wars, Prof. Lapicque played a decisive part in the development of physiology in France. He was a welcome figure at international gatherings, where he spoke lucidly and with conviction on the problems of scientific co-operation. Vigorous in body as in mind, a keen yachtsman and a charming host, he was a worthy representative of the great traditions of his country.

E. D. Adrian

\section{NEWS and VIEWS}

Chair of Mining in the Imperial College, London : Prof. J. A. S. Ritson

Prof. J. A. S. RITSon vacated the University of London chair of mining at the Royal School of Mines, Imperial College, in October 1952, after a distinguished tenure of seventeen years. $\mathrm{He}$ is a graduate of the University of Durham, and started his professional career as inspector of mines in the Scottish, Yorkshire and South Wales coalfields. After distinguished service in the Army during the First World War he occupied the chair of mining in the University of Leeds during 1923-35, where he devoted much of his research to the improvement of mine rescue appliances and shot-firing techniques. Since his appointment to the Royal School of Mines, Prof. Ritson has maintained his keen interest in coal mining, and rapidly gained a high reputation as an expert on problems of metalliferous mining, based on experience won in various parts of the world. Among his multifarious duties he has acted for many years as Crown mineral agent, as a member of the Coal Commission, and as deputy chairman of the Mineral Resources Committee of the Ministry of Fuel and Power ; during the Second World War he joined that Ministry for a 